\title{
The Limits of Transparency: Expert Knowledge and Meaningful Accountability in Central Banking
}

\author{
Eugénia C. Heldt ${ }^{1 \star}$ (iD) and Lisa $\operatorname{Herzog}^{2}$ \\ ${ }^{1}$ TUM School of Governance, Technical University of Munich, Munich, Germany, and ${ }^{2}$ Department of \\ Philosophy, University of Groningen, Groningen, the Netherlands \\ ${ }^{*}$ Corresponding author. Email: eugenia.heldt@hfp.tum.de
}

(Received 5 June 2020; revised 23 November 2020; accepted 30 November 2020;

first published online 26 January 2021)

\begin{abstract}
Recent discussions of accountability in contexts of expert knowledge raise questions about the limits of transparency. Against this background, we discuss the nexus between expert knowledge and meaningful accountability - that is, context-sensitive accountability based on a genuine understanding of a situation. We argue that the concentration of expertise in certain institutions makes it difficult to hold those institutions accountable. In particular, three components challenge meaningful accountability: specialization, inaccessibility and potential biases or conflict of interest. We emphasize the role of 'epistemic communities' and their impact on the tension between expert knowledge and independence. Drawing on the deliberative systems literature, we discuss how expert knowledge might be communicated to outsiders to enable meaningful accountability. To illustrate our argument, we draw on the European Central Bank, a case study in which states have chosen a delegation design characterized by a high degree of independence and trust in expert knowledge, to the detriment of accountability. We sketch possible avenues for creating the conditions for meaningful accountability even in the case of institutions with highly concentrated expertise.
\end{abstract}

Keywords: accountability; expert knowledge; European Central Bank; epistemic communities; deliberative systems

Accountability is considered a 'virtue' of political institutions (Bovens 2010), but there is disagreement about what it actually is. In recent years, there have been many pleas to rethink existing accountability practices. For example, in the concluding chapter of the 2014 Oxford Handbook of Public Accountability, Mark Bovens and Thomas Schillemans (2014: 674) write that research on 'meaningful accountability' is needed, which would move from mechanical forms of 'one size fits all' accountability to better designs that take the specificities of different 'conditions and contexts' into account. In what follows, 'meaningful accountability' means context-sensitive accountability based on a genuine understanding of a situation.

(C) The Author(s) 2021. Published by Cambridge University Press on behalf of Government and Opposition Limited. This is an Open Access article, distributed under the terms of the Creative Commons Attribution licence (http://creativecommons.org/licenses/by/4.0/), which permits unrestricted re-use, distribution, and reproduction in any medium, provided the original work is properly cited. 
We focus on one particular challenge for meaningful accountability: expert knowledge. In the delegation literature, accountability presupposes a relationship between principals (states) and agents (specialized institutions). Accountability mechanisms are in place to keep agents in line and to avoid abuses of power. Thus, accountability includes a process whereby actors answer for their conduct to those whom they affect (Scholte 2011). This allows principals to judge whether agents have fulfilled their responsibilities, and to impose sanctions if they have failed to do so (Grant and Keohane 2005: 29). A central element in many definitions of accountability is the transmission of information, often captured by the terms 'transparency' or 'answerability' (see e.g. Ebrahim and Weisband 2007; Heldt 2018; Hood 2010; Jabko 2009; Scholte 2011).

However, in many accountability processes, those who are being held accountable know more than those who are supposed to hold them accountable. While both groups may be experts in the sense of having a certain educational background, the former are far more deeply involved in the concrete tasks and therefore have more expert knowledge. This expert knowledge might be used strategically, not used at all, or used only in symbolic ways (Schrefler 2010: 319).

This problem is particularly relevant for organizations in which expert knowledge is concentrated, which makes it difficult to find independent communities of experts to hold them accountable. To discuss this constellation, we draw on the literature on deliberative systems (Mansbridge et al. 2012). While the focus of this piece - independent expert institutions instead of democratic discourse more broadly speaking - is different, many arguments about the relation between experts and outsiders are relevant in both cases.

We use the case of central banks, and in particular the European Central Bank (ECB), to illustrate our argument. This case presents a particularly hard challenge when it comes to enabling meaningful accountability. Usually, independence rather than accountability is seen as the cornerstone of central banks. Monetary policy, like the work of independent regulatory authorities, is seen as a purely technical domain based on expert knowledge with few accountability mechanisms (Best 2016; Koop and Hanretty 2018; Marcussen 2009). When the ECB was created, for example, there was a lively debate about questions of independence and accountability (Buiter 1999; Issing 1999). Willem Buiter (1999: 187) argued that the ECB lacked political legitimacy because of its lack of transparency and openness. Otmar Issing (1999: 510), in contrast, defended the existing ECB design for its high level of independence and weakly developed institutional and public accountability mechanisms.

With the financial crises of the past years, however, the expansion of central bank powers raised concerns about legitimacy (see e.g. Dietsch 2019; Dietsch et al. 2018; Fontan 2018; Jones and Matthijs 2019; van't Klooster 2018), accountability (Braun 2017; McNamara 2012) and self-empowerment (Heldt and Müller 2020), with criticism from populist parties, academics and civil society groups (Fontan et al. 2018). They challenged the idea that we should blindly trust central bankers simply because they are 'experts' (Riles 2018). For example, on the institutional side new controversies included the legal dispute involving the German Federal Constitutional Court and the European Court of Justice on the grounds that the ECB had overstepped its mandate. Following the German Federal Constitutional Court answer to Gauweiler, some legal scholars (e.g. Di Fabio 2014; Petersen 2014) questioned the 
compatibility of the ECB's actions in the outright monetary transactions programme. The fact that the German court refused to follow the ruling of the European Court of Justice concerning the bond-buying programme undertaken by the ECB was described as setting 'a bomb under the EU legal order' (Grimm 2020). ${ }^{1}$ On the public side, contestation of the ECB role led to the emergence of the 'blockupy' movement, as an open attempt to Europeanize radical protest by questioning the authority and legitimacy of the ECB (della Porta 2020).

The politicization of ECB action fuelled the academic discussion on how the ECB should navigate between independence and accountability. Whilst Deirdre Curtin (2017) underlines the tension between the need for greater openness and transparency and the preservation of independence, Mark Dawson et al. (2019) contrast the procedural and substantive accountability of the ECB. They conclude that accountability is a complex exercise that privileges independence with extensive procedural levels over substantive accountability. As an alternative approach, Gijs Jan Brandsma and Johan Adriaensen (2017) suggest increasing the ECB's 'throughput legitimacy', which consists in governance processes with the people (Schmidt 2013). However, more recent studies suggest that this concept has not really been helpful in addressing the issue of democratic controls over independent agencies (Steffek 2018).

Our article adds to this literature by focusing on the epistemic dimension of meaningful accountability, proposing the establishment of an independent advisory board to overcome these challenges. We show that, from an epistemic angle, there are three challenges to meaningful accountability: specialization, inaccessibility and potential biases. In so doing, we emphasize the role of 'epistemic communities' (Haas 1992): many experts who might play a role in holding central banks accountable are also members of the 'epistemic communities' that centre on these very institutions. Epistemic communities tend to open up their knowledge networks to like-minded allies, while closing themselves off to others (Marcussen 2009), which creates particular challenges for accountability.

In the next section we describe the challenge of expert knowledge for meaningful accountability, first in general terms and then with regard to central banks. We then turn to the literature on deliberative systems and its reflections on how expert knowledge can be communicated to outsiders. We illustrate our argument by discussing ECB accountability, suggesting that what is needed is an independent community of experts who can help citizens in holding it accountable. In so doing, we complement other studies that examine the independence and accountability of the ECB (Braun 2020; Curtin 2017; De Haan and Eijffinger 2000; Howarth and Loedel 2005; Jabko 2009).

\section{Meaningful accountability and the challenge of expert knowledge}

One of the main characteristics of modern societies is 'hyper-specialization' (Millgram 2015). Together with the specialization of tasks comes the differentiation of knowledge. As a consequence, many forms of theoretical knowledge and practical know-how are not readily available to outsiders, but only to the relevant experts. The superior knowledge of experts often stems from years of immersion in local circumstances or practices (Collins and Evans 2004). Experts constitute what Ernst Haas (1992: 2-3) calls 'epistemic communities', 'networks of 
knowledge-based experts' that shape decision-making processes in global governance. Haas focused on professionals who share sets of 'normative and principled beliefs', 'causal beliefs' and 'notions of validity' and who pursue 'common policy enterprise'. In this contribution, we use the term in a looser sense to describe communities that share an educational background, a specialization, and often also a worldview. Epistemic communities typically use a certain jargon and communicate by means of codes and symbols opaque to non-experts.

The inaccessibility of many forms of knowledge to outsiders from the relevant epistemic communities leads to a further problem: that of potential biases or conflicts of interest. In many cases, understanding the ins and outs of a practice or institution requires a certain degree of closeness to its members. This leads to a dilemma when it comes to accountability: in order to acquire the necessary interpretive skills, one needs to be close to the community in question; in order to hold them accountable, in contrast, one needs to be impartial, which requires a certain distance. Onora O'Neill captures this tension well: 'There is an old saying that those who know cannot judge fairly, while those who can judge fairly know too little to provide an informed judgement. This is no doubt an exaggeration, but the tension between informed and independent judgement is real' (2014: 184-185). While we do not think that this problem is insurmountable, we take it to be a real - and under-appreciated - challenge for hyper-specialized societies. It mars various forms of accountability - for example, by peers or within hierarchies or supervisory relations (see e.g. Grant and Keohane 2005).

In contrast, those who want to use other forms of accountability - Ruth Grant and Robert Keohane (2005) also list fiscal, legal, market and public reputational mechanisms - need to overcome the opposite problem of not truly understanding what specialized institutions do. These forms of accountability are marred by the incentives for insiders to use knowledge strategically. Accountability often comes with the threat of sanctions, which means that those who are held accountable might want to use their superior knowledge in ways that steer the outcomes of accountability processes in certain directions.

These three related phenomena of specialization, inaccessibility and the risk of bias or conflict of interest can also be found when it comes to central banking. Central banks rely on epistemic communities whose members share the same educational background and ideology. The scientization of central banking implies that knowledge is concentrated in the hands of those experts who master the discourse of the relevant scientific fields as well as scientific 'techno-speak' (Marcussen 2009). Central banks' power and authority arise from their specialized knowledge (Alter 2008) and impartiality (Adolph 2013). Epistemic authority is crucial for maintaining their authority - but it can put meaningful accountability at risk.

These challenges of specialization, inaccessibility and the risk of bias or conflict of interest need to be taken seriously when thinking about accountability. One fundamental implication is that transparency - in the sense of an open sharing of data and information - is often far from sufficient for accountability to be meaningful, because non-experts cannot interpret and properly contextualize the information that is made available (O’Neill 2014: 183). If these challenges are neglected, or overshadowed by instinctive calls for 'more transparency', accountability mechanisms run the risk of becoming meaningless. 
These problems have not received sufficient attention in the literature on accountability, with one notable recent exception. Cathrine Holst and Anders Molander (2017: 235) speak of the basic 'fact of expertise' that all modern societies need to deal with: they depend on various forms of expertise that are not accessible to non-experts. This raises fundamental questions for democratic governance: while democracy is based on the imperative of treating all citizens equally, expertise calls for differentiation (see also Dyson and Featherstone 1999: 801). As Holst and Molander emphasize, 'the central question from an epistemic perspective is ... how one can ensure that identified experts perform their democratically entrusted tasks in an acceptable manner' (2017: 241). This means, for example, that one needs to pay attention to the risk of fallacies or motivated reasoning on the parts of experts. Experts' behaviour, their judgements and the 'conditions for expert enquiry and judgement' (Holst and Molander 2017: 243) need to be brought into line with their tasks.

Holst and Molander's study is an important step forward in thinking about the challenges of expert knowledge in the context of practices of accountability. As we will make clear below, we go further by emphasizing the tensions that can arise between sanctions and knowledge-sharing, especially in antagonistic situations. We also add the argument about epistemic communities being centred on certain institutions in ways that make it difficult for third parties to obtain an objective picture. In the next section, we discuss in more detail how the problem of communication between experts and the broader public has been treated from a normative perspective in the deliberative systems and related approaches.

\section{Communication with experts: the deliberative systems perspective}

The challenge of increasing the accountability of institutions in which expert knowledge is hosted is neither new nor completely insurmountable. To understand how accountability can function in such contexts, it is helpful to draw on the deliberative systems approach developed by Jane Mansbridge and colleagues (2012). They underline that, in well-functioning democracies, there are numerous institutions with different roles (e.g. investigative journalists, antagonistic political players, etc.) that contribute to the deliberative system. What matters is that they achieve ethical, political and epistemic aims together: to promote 'mutual respect among citizens', to ensure that all groups in society have a voice and to ensure 'reasonably sound decisions' (Mansbridge et al. 2012: 11-12). This latter 'epistemic' aim includes integrating expert knowledge into the general public discourse.

For the accountability of experts, it makes sense to think in similar 'systemic' terms: the challenge of holding experts accountable cannot be reduced to a constellation of 'the experts' on the one side and 'the general public' on the other. Rather, there are various intermediary institutions and translation mechanisms. In both the deliberative systems approach and the literature on expertise, we find a number of proposals for how communication between experts and laypeople could and should work.

One important contribution is from Thomas Christiano (2012), who discusses a number of mechanisms that allow democratic systems to integrate different forms of expertise. 'Solidarity' between experts and non-experts on the basis of 'similarity of backgrounds and like-mindedness' means that they can trust each other. 
'Overlapping understanding' between different experts and non-experts allows for a chain of translation from highly specialized experts to laypeople. 'Competition' 'within and between political parties' weeds out inappropriate claims to expertise in an 'adversarial system'. Finally, 'sanctions' penalize the abuse of expertise (Christiano 2012: 38, 39-40, 41-42). Christiano (2012: 49) also argues for the importance of 'robust debate among a variety of different kinds of theories' in order to prevent 'parochialism, group-think, and cognitive bias'. Other authors have suggested additional mechanisms - for example, behavioural norms for experts or peer review in science (Holst and Molander 2017: 242-246). We can summarize these various proposals in three broad categories, which often operate in conjunction in cases of successful communication between experts and laypeople.

Shared agendas. To some extent, laypeople have to trust experts, but they should do so for good reason. If experts share the same agenda, laypeople can be reassured that they are not placing their trust naively.

Translation. Based on chains of 'overlapping understanding', some forms of expert knowledge can be translated to laypeople. Here, a relevant concept is Harry Collins and Robert Evans's (2004: 14) notion of 'interactional expertise': 'the ability to master the language of a specialist domain in the absence of practical competence'. It allows specialized journalists, for example, to ask scientists critical questions and to communicate the answers to the general public.

Competent antagonism. When knowledge is created and transmitted to others, it needs to be checked by controlled forms of antagonism, in which prejudices, blind spots or forms of groupthink can be detected and amended. But this antagonism needs to come from individuals who have sufficient competence; mere public slander does little to facilitate the communication of knowledge. Competent antagonism, in contrast, often comes with explanations and the description of alternative courses of action. Without the presence of such competent antagonism, laypeople cannot be expected to place trust in experts. Christiano's (2012) notions of 'competition' and 'sanction' point in that direction, as does Holst and Molander's (2017) emphasis on peer review and on 'cognitive diversity'.

As these considerations show, successful communication between experts and laypeople can be expected to succeed only if certain structural conditions are fulfilled. We now proceed to illustrate our argument by focusing on the ECB. This serves to demonstrate the challenges of meaningful accountability in the face of highly concentrated expertise, with an epistemic community that is, to a great extent, centred on a specific institution.

\section{Central banking: the challenges of meaningful accountability illustrated}

Central banks are often cited as a standard case of an independent technocratic institution in democracies (e.g. Marcussen 2009). There are four main reasons why states delegate power to central banks. First, states expect central bankers to act according to their personal reputation and professional norms. Second, central bankers are entrusted with independent authority to make decisions according to their best judgement or professional criteria. Third, central bankers are empowered to act on behalf of their beneficiaries (Alter 2008); these are not only politicians but also citizens. Fourth, a high degree of central bank independence is an almost 
necessary condition for credible monetary policy, as it enables central bankers to convince market participants that they are really determined to curb inflation.

For a long time, the technocratic authority of central banks went relatively unquestioned. During the euro crisis, however, the ECB's decision to adopt political measures to save the common currency, including the establishment of the outright monetary transactions programme allowing the ECB to buy sovereign debt, led to controversial discussions on whether the ECB had overstepped its mandate. Concerns about a lack of accountability were raised; in fact, some scholars claim that the ECB has struggled with the tension between the need for greater transparency and the need for secrecy from its inception (Braun 2020; Curtin 2017). The question of how an institution such as the ECB can be held accountable by outsiders has become urgent (Riles 2018; see also Best 2016; van't Klooster 2019). But could this be meaningfully achieved, given the knowledge gap between experts and laypeople?

When it comes to shared agendas, understood as the ability of laypeople to trust experts, communication can work only if central bankers render public accountability for matters of public interest to laypeople (citizens) or to their parliamentary representatives. Even though the new president of the ECB, Christine Lagarde, intends to strengthen this dimension and has even recently met with French and German members of parliament in an online conference, this dimension is still hardly developed, with few possibilities for laypeople to place trust on the basis of shared agendas or similar mechanisms. This is not surprising in the case of the ECB, as member states intentionally designed a highly independent bank with vertical accountability mechanisms rather than horizontal ones (see also Grant and Keohane 2005).

For other central banks, a mechanism of 'shared agendas' between political parties (and hence indirectly laypeople as their voters) and central bankers can operate through appointment procedures - as Henry Chappell and colleagues (1993) and Christopher Adolph (2013) have shown with regard to the Federal Open Market Committee in the US - since appointments play an important role, along party lines, in different approaches to monetary politics (see also Sylvester Eijffinger et al. (2018) on the composition of the monetary policy committee of the Bank of England in the UK). Adolph's (2013) study also challenges the common wisdom that central bankers are insulated from politics. He shows that partisan appointments to central banks constitute an important link in democratic control of the economy. Whether a layperson shares the agenda with central bankers may reflect that person's ideological preferences. In the US, for example, Democrats and Republicans tend to have different expectations of the Federal Reserve Board. ${ }^{2}$ In the case of the ECB, the situation is more complex because there are appointees from different countries and many European countries have more complex party landscapes. ${ }^{3}$

The gap between accountability holders (laypeople) and accountability givers (central bankers) is increased by the communication bubble of economic and legal experts within central banks, who use a jargon not accessible to laypeople, which is also an obstacle to translation. Economic experts often belong to the same epistemic community as the ECB officials, and it is not clear whether they have an interest in strong accountability. There is a further challenge. In addition to the broader public and politicians, there is a specific audience that central 
banks need to be very careful about: financial markets. Some information that could interest other audiences ought not to be disclosed to prevent markets from 'gaming' central bank operations. ${ }^{4}$ There is, of course, a potential trade-off between better openness and meaningful accountability and level of trust by market operators towards the ECB.

One group forms an exception here: members of the European Parliament (EP). For example, when the euro crisis reached its peak, members of the EP had a strong incentive to demand accountability from the ECB. However, the ECB reacted very reluctantly to these concerns. When, in 2014, the EP issued a report asking about the engagement of the troika institutions with national parliaments, the ECB simply declared that it was 'not accountable to national parliaments' (European Parliament 2014). Finance ministers, however, prioritized the stability of the currency and trusted the epistemic authority of the ECB to solve the crisis (Van Rompuy 2012). Thus, in a sense there was a shared agenda, but one that worked against public accountability: instead of those being held accountable sharing an interest in accountability to a broader public, both those who could have held them accountable (finance ministers) and the institution (the ECB) showed hardly any taste for public accountability.

Historically, transparency or translatability has not been high on the agenda of many central banks, as epitomized in Alan Greenspan's famous 1988 quote: 'I guess I should warn you, if I turn out to be particularly clear, you've probably misunderstood what I've said.' The general tendency has been towards more transparency, but the ECB was rather tardy in following the trend. After a wave of criticism on limited transparency, the ECB finally decided to strengthen its venues of communication with the public. These include press conferences, executive board communications guidelines and the ECB forum on central banking (European Central Bank 2019) all mechanisms that one could read as attempts to provide more translation of expert knowledge to the broader public. However, many of these steps remain rather limited, not least because of the use of economic jargon (see also Riles 2018: 64).

Generally speaking, mechanisms of translation were only weakly developed in the case of the ECB. The most developed interactions between the ECB and nonexperts are its press conferences and the annual forum on central banking in Sintra with central bank governors, academics, high-level financial market representatives and journalists (European Central Bank 2019). Additional public accountability mechanisms include a new section on the ECB website about accountability issues and the establishment of a so-called youth dialogue initiative, where the ECB president answers questions sent in on Twitter and Facebook to increase the bank's responsiveness to non-experts. ${ }^{5}$ But young people are usually not in a position to really question ECB policies, so this cannot be described as a form of competent antagonism. Even though these new initiatives of 'going public' may be successful in making the ECB appear more accessible, they fail to get to the crux of what meaningful accountability is about.

More recently, ECB president Christine Lagarde has decided to strengthen the transparency efforts of the bank. One of the most important initiatives so far has been the creation of a new portal, the 'ECB Listen Portal', in which citizens, by participating in a survey, can have a say in the ECB's strategy review. Questions include price stability, economic expectations and concerns, and how the ECB can best 
communicate with citizens. ${ }^{6}$ This strategy of strengthening communication with the public aims at regaining public trust. For example, ECB staff participate regularly in academic conferences to demonstrate the willingness of the ECB to engage with the public (see Gardt et al. 2019) and to strategically produce and disseminate 'scientific research' supporting its policy ideas (see also Mudge and Vauchez 2016). However, it remains to be seen whether these attempts at communication will be taken up by other agents who can translate them to the broader public.

The third category of mechanisms, competent antagonism, is not strongly developed in the case of the ECB either. One subcategory, Christiano's (2012) notion of 'competition', falls flat simply because there are no institutional competitors (apart from national central banks, which fulfil a different role). Member states cannot claim that they will turn to the services of another supranational institution in case of dissatisfaction with the ECB. One might ask whether the competition between other organizations - for example between different parties in the EP could help strengthen ECB accountability. However, this seems unlikely because the EP cannot use any sanctions against the ECB; EP members thus have no incentive to scrutinize ECB practices. The ECB's independence protects it from such mechanisms, not only vis-à-vis the EP, but also with regard to other actors, such as national ministries, who might potentially compete for public attention and thereby be induced to hold the ECB accountable.

Sanctions, as another element of competent antagonism, are also only weakly developed. Credible sanction mechanisms that states use for other European institutions, such as budget contraction, do not apply to the ECB. As an alternative, concern about its reputation might be one of the more credible mechanisms that non-experts can use to hold central bankers accountable. Central bankers might put their professional reputation at risk, and decreasing peer support might result in a loss of prestige. However, such a loss of reputation is likely to be effective only if it is supported by the judgement of the relevant expert group - economists. But central bankers often come from the same business schools and economics departments as the macroeconomists who might be able to evaluate their work critically (e.g. Riles 2018).

The recent conflict between the German Federal Constitutional Court and the ECB might be considered a case of competent antagonism. The Constitutional Court questioned the authority and mandate of the ECB in relation to the corporate and public sector purchase programme. It requested the ECB to provide a comprehensible explanation of proportionality between the monetary policy objective of price stability and the economic policy effects of these programmes. This legal dispute reveals that the ECB slipped into this conflict of competence with the Constitutional Court partly because it failed to come up with persuasive descriptions of alternative courses of action in relation to its extensive bond purchasing programmes for the public and corporate sectors. The absence of such competent antagonism might have initially reduced laypeople's trust in the central bank. In the meantime, the intrusion of the Federal Constitutional Court into the ECB's purchasing has raised the question of whether the German court itself had not surpassed its mandate by judging the actions of the ECB. This also led national and supranational institutions to come to the defence of the central bank. Nevertheless, one can say that 'fear' of judgement itself raised concerns about 
accountability and awareness of the need to better communicate monetary politics to laypeople. As Christine Lagarde put it recently in relation to price stability: 'We need to explain to the general public much better what we are doing and why, and we need to talk to people we normally don't reach' (cited in Weigner 2020).

One might ask whether financial practitioners, in private financial institutions, could be another group with sufficient understanding, but also sufficient independence, to help translate and publicly evaluate central bank policies. But this is unlikely to be a promising strategy. First, as employees of profit-oriented organizations, economists employed by private banks are likely to have an agenda of their own (or of their employer!) when making public statements. Second, many individuals working in the financial system have followed similar educational paths to central bankers, and hence share the mindset and prestige economy.

A striking detail in this context, which has already attracted public criticism, is that the former head of the ECB, Mario Draghi, was apparently still a member of the G30 group - a Washington-based exclusive group of high-profile bankers during his mandate as ECB president. Even though the European ombudsman, Emily O'Reilly, rightly pointed out that this membership could damage the reputation of the bank, Draghi remained a member of this group (Boffey 2018). While this issue raises questions of its own - especially given the secrecy that surrounds the G30 - it was also an indicator that a top ECB official seemed to share the mindset and ideological views of influential figures in the financial sector, again raising questions about the closeness of this epistemic community. ${ }^{7}$

As Annelise Riles's ethnographic work shows, the self-understanding of central bankers is that of 'financial engineers' (Riles 2018) - that is, skilled, neutral officials who get things 'right' (see also Adolph 2013 on the 'myth of neutrality'). Central bankers have been presented, and also sometimes present themselves, as 'passionless machines and specialists without spirit' (Marcussen 2009: 377). They see themselves as having expertise in macroeconomic issues, which they consider the only expertise relevant to their job. Therefore, they are often not willing to use simple language to make themselves understood to the general public. Instead, they prefer to speak to their own epistemic community.

Finally, when external experts - macroeconomists working at universities, for example - try to evaluate central bank policies in the sense of competent antagonism, it is very possible that conflicts of interest arise, mostly concerning professional standing and reputation. These external experts might have their own careers in mind when assessing the performance of a central bank, in the sense that they might be forward-looking rent-seekers (see also Adolph 2013) hoping to be hired by the institution they are evaluating.

Academic macroeconomists often collaborate with economists who work for central banks and might also depend on them for access to data. As Peter Dietsch et al. (2018: 89) show, in journals focusing on macroeconomic issues, many articles - 39\% on average between 2006 and 2015 - had at least one co-author from a central bank; there are also numerous ties through visiting fellowships and consultancy contracts. While the close collaboration between central banks and academic research communities certainly has advantages, it endangers certain mechanisms of 'effective error-correction', especially 'sustained' and 'varied' criticism (Dietsch et al. 2018: 79-81). But for a field of expertise to keep its vitality, ongoing 
contestation and discussion of its premises are needed. 'Groupthink' (Janis 1992) can dangerously narrow down one's perspective and make experts vulnerable to the risk of overlooking important issues (see also Holst and Molander 2017: 243). ${ }^{8}$

These issues are also problematic from the point of view of independent accountability, because researchers might be biased towards results in line with central policies in order not to endanger career options (Dietsch et al. 2018: 92). Those who understand central banking best are likely to be too close to central banks to be sufficiently independent for meaningful accountability because competent antagonism is undermined.

Are there any ways forward in this situation? One strategy would be to appeal to the moral virtues of central bankers to take their responsibility for society seriously even if they cannot be held accountable in meaningful ways. Many contributions to the literature on accountability emphasize the importance of the right attitude among those who are held accountable, naming principles such as 'honesty', 'precision', 'audience relevance', 'process transparency' and 'specification of uncertainty about conclusions' (Keohane et al. 2014, 352).

It is certainly not wrong to emphasize the moral responsibilities of experts in hyper-specialized societies. But from a democratic perspective, such an appeal to morality is unsatisfactory. It would mean that the whole of society would depend on the goodwill and honesty of a small number of people, without any possibility of control. Experts, including ECB experts, are human beings who are subject to bias and error, or who might pursue their own interests or convictions (see also Holst and Molander 2017). Expecting them to use their power wisely and responsibly without providing any control mechanisms is unrealistic. In a democracy, power requires accountability, not only to prevent abuse, but also as a matter of respect between the citizens of a society who see themselves as moral equals (see e.g. Ceva and Radoilska 2018).

Instead of giving up on the idea of accountability, it seems more promising to ask how mechanisms of accountability could be improved and work hand in hand with the moral responsibility of experts. What seems particularly urgent in the case of the $\mathrm{ECB}$ is to enable more competent antagonism. The core challenge here is to nurture an independent community of experts that could support citizens in holding central banks accountable (see also Dietsch et al. 2018: 107). ${ }^{9}$ These external experts should have sufficient 'interactive' expertise in the sense of Collins and Evans (2004: 14), so that they could also support mechanisms of translation.

Such experts could, for example, be economic journalists or academics from different disciplines - including philosophy, political science and sociology - or economists from other subfields, who do not have any potential conflicts of interest but can nonetheless understand the activities of central bankers sufficiently well to serve as translators. They could also include experts employed by civil society organizations who are competent but at least in part antagonistic to the mainstream and could add a complementary mindset to ECB thinking. ${ }^{10}$ They could thus help to bring about meaningful accountability, in which there is informed and independent judgement of performance, complemented by intelligible communication of those judgements' (O’Neill 2014: 184). ${ }^{11}$

A more ambitious proposal would be to take steps towards including nonexperts in an independent deliberative body that holds central bankers accountable, 
enabling the citizenry at large to share an agenda with this advisory body. Such a body could constitute an independent advisory board with a variety of members. To ensure competence, the majority of members should be experts, but experts nominated by civil society organizations, which would ensure a shared agenda with different parts of society. ${ }^{12}$ Some experts could come from the monetary policy field and others from fields affected by such policy - for example, from organizations active in consumer protection - to ensure cognitive diversity and a plurality of perspective (see similarly Holst and Molander 2017: 246; Riles 2018: 85-89). ${ }^{13}$

To minimize the risk of capture, members of the advisory board could be independent of the central bank and have limited terms to ensure regular rotation. ${ }^{14}$ With regard to rights in and access to decision-making processes, such an advisory board would have different scenarios - differing in competence, from mere consultation to veto powers for certain policy areas. For example, the United Nations has started to experiment with such external advisory boards, so some experience and 'good practices' could be taken over from existing models. Transnational access to the ECB could have different degrees of depth (right to vote vs. passive observer) and range of access (all interested vs. only experts) as well as the permanence (permanent vs. invitation only) and codification of access (treaty provision vs. guidelines) (Tallberg et al. 2013: 28).

An additional advantage is that in discussions that cannot be made public to avoid disturbing financial markets, practices of 'qualified transparency' (as proposed by Pasquale 2010 in the context of accountability of internet intermediaries) could be used. For other policy areas, in contrast, the members of this advisory board could engage in activities of 'translation', for instance translating discussions to a broader public. This would contribute to creating an 'issue public' (Elliott 2020) that would increase accountability for central bank practices. ${ }^{15}$

\section{Conclusion}

In this piece, we have discussed the problem of accountability in the face of hyper-specialized knowledge. We have analysed the problems of specialization, inaccessibility, and potential conflicts of interest or biases, emphasizing the role of epistemic communities for many forms of specialized knowledge. We have argued that to overcome these challenges to accountability, a systemic approach inspired by the deliberative systems approach is most promising. We have taken the case of the ECB to illustrate the epistemic challenges to accountability in the case of institutions with concentrated expertise, arguing that the mechanisms that help to build bridges between experts and laypeople in other contexts are underdeveloped, while accountability to peers is made difficult by the fact that many experts in macroeconomics are themselves members of the epistemic community of central bankers and/or have potentially conflicting interests. We have argued that in order to make meaningful accountability possible, an independent community of experts should be nurtured, and we have also proposed more far-ranging possibilities for improving the accountability process - for example, through independent advisory boards.

Riles (2018) emphasizes that citizens and politicians have a responsibility to educate themselves about macroeconomic issues in order to exercise 'financial citizenship'. But 
in this area, as in others where highly specialized expertise is at stake, citizens and politicians need help from experts and translators who can ensure meaningful accountability. The great danger with regard to central banking and other areas with similar constellations is that such steps are taken only when a scandal or crisis occurs. Political incentives to build structures for meaningful accountability are often greatest after such an event. But the aim of meaningful accountability would be precisely to prevent such crises or scandals. Developing the structures that make it possible is thus an investment in political stability, and a way forward for reconciling the benefits of specialization with the values of democracy.

Acknowledgements. This research has received funding from the European Research Council under the European Union's Seventh Framework Programme for research, technological development and demonstration under grant agreement no. 312368 DELPOWIO (Delegation of Power to International Organizations and Empowerment over Time). We are also grateful for the generous funding from the German Research Foundation under grant agreement DFG CO 850/5-1. The authors thank the audience at the PPE colloquium, Groningen University, and colleagues at the Chair of European and Global Governance colloquium for their comments on earlier versions of this article. In addition, we want to thank Erik Jones, Laura Cram, Tony Mueller, and three reviewers of Government and Opposition for their very helpful comments on this piece. Both authors contributed equally to this paper.

\section{Notes}

1 For an overview of this extensive literature see German Law Journal 2015 16(6) (special issue on the Federal Constitutional Court answer to Gauweiler) and German Law Journal 2020 21(5) (special issue on the Weiss case).

2 To the best of our knowledge, there has been no comparable research on partisan considerations in the appointment of ECB members. Whilst Schulz (2017) has examined individual ECB staff characteristics (country of origin, education and work experience), partisan appointment at the ECB has yet to be studied. 3 In the case of the ECB, we are well aware that agendas that have to be shared might simply differ. In this case, trust in the expertise of central bankers becomes even more important. We assume that shared agendas is one of three central elements in achieving meaningful accountability without taking the next step in examining diverging positions on shared agendas. We are grateful that one anonymous reviewer raised this point. This could be a highly interesting topic for a dissertation project, but beyond the scope of this article. 4 An example that illustrates this point are ECB purchases of bonds under the Corporate Sector Purchase Programme. We thank an anonymous reviewer for raising this point and citing this example.

5 For the page on accountability issues, see www.ecb.europa.eu/ecb/orga/accountability/html/index.en. html. For the youth dialogue, see https://www.ecb.europa.eu/ecb/educational/youth-initiatives/ecb-youthdialogue/html/index.en.html.

6 See www.ecb.europa.eu/home/search/review/html/form.en.html.

7 The situation of the Federal Reserve Board in the US is comparable, see Riles (2018: 17-19).

8 As a recent survey study of central bankers shows, the ECB views are not internally consistent. It is 'stuck in the middle between a revisionist South and an orthodox North' (Schulz 2017: 118). This internal differentiation, however, does not solve the more coarse-grained problem that central bankers and macroeconomists still come from a shared background and that there is a culture clash with, for example, members of NGOs.

9 Dietsch et al. (2018: ch. 5) also suggest increasing diversity among central bank staff and separating short-term regulatory tasks from the long-term research tasks of central banks to ensure that the latter can allow genuine contestation. However, this proposal - while certainly noteworthy - is not sufficient to secure meaningful accountability to external agents.

10 A comparable case is the Bank Information Center (https://bankinformationcenter.org), which monitors the World Bank and development finance in general. We thank a reviewer for drawing our attention to this example.

11 Van't Klooster (2019) suggests a 'eurozone parliament' to hold the ECB accountable. However, such a parliament would only be able to fulfil its functions if it could either rely on or create such a community of experts. 
12 One might also consider including 'normal citizens' drawn by lot, along the lines successfully implemented in 'mini publics' (see e.g. Fishkin 2018). This could add cognitive diversity to the board.

13 To be sure, such experts from different fields could be accused of lacking macroeconomic competence (Marcussen 2009), but we take it that by participating in such an advisory board, experts would acquire sufficient expertise (at least in the sense of 'interactional expertise', cf. Collins and Evans 2004).

14 Costs and honoraria could be paid by the civil society organizations sending the delegates.

15 As such, it could also help to prevent abuses of power such as interference with independent research or informal sanctions against critical journalists.

\section{References}

Adolph C (2013) Bankers, Bureaucrats, and Central Bank Politics: The Myth of Neutrality. Cambridge: Cambridge University Press.

Alter K (2008) Agents or Trustees? International Courts in Their Political Context. European Journal of International Relations 14(1), 33-63. https://doi.org/10.1177\%2F1354066107087769.

Best J (2016) Rethinking Central Bank Accountability in Uncertain Times. Ethics \& International Affairs 30(2), 215-232. https://doi.org/10.1017/S0892679416000095.

Boffey D (2018) Mario Draghi Told to Drop Membership of Secretive Bankers' Club. Guardian, 17 January. www. theguardian.com/business/2018/jan/17/mario-draghi-ecb-drop-membership-secretive-bankers-g30-club.

Bovens M (2010) Two Concepts of Accountability: Accountability as a Virtue and as a Mechanism. West European Politics 33, 946-967. https://doi.org/10.1080/01402382.2010.486119.

Bovens M and Schillemans T (2014) Meaningful Accountability. In Bovens M, Goodin RE and Schillemans T (eds), The Oxford Handbook of Public Accountability. Oxford: Oxford University Press, pp. 673-682.

Brandsma GJ and Adriaensen J (2017) The Principal-Agent Model, Accountability and Democratic Legitimacy. In Delreux $\mathrm{T}$ and Adriaensen J (eds), The Principal-Agent Model and the European Union. Basingstoke: Palgrave Macmillan, pp. 35-54.

Braun B (2017) Two Sides of the Same Coin? Independence and Accountability of the European Central Bank. Brussels: Transparency International EU.

Braun B (2020) Central Banking and the Infrastructural Power of Finance: The Case of ECB Support for Repo and Securitization Markets. Socio-Economic Review 18(2), 395-418. https://doi.org/10.1093/ser/mwy008.

Buiter WH (1999) Alice in Euroland. Journal of Common Market Studies 37(2), 181-209. https:/doi.org/ 10.1111/1468-5965.00159.

Ceva E and Radoilska L (2018) Responsibility for Reason-Giving: The Case of Individual Tainted Reasoning in Systemic Corruption. Ethical Theory and Moral Practice 21(4), 789-809. https://doi.org/ 10.1007/s10677-018-9950-2.

Chappell HW, Havrilesky TM and McGregor RR (1993) Partisan Monetary Policies: Presidential Influence Through the Power of Appointment. Quarterly Journal of Economics 108(1), 185-218. https://doi.org/10.2307/2118500.

Christiano T (2012) Rational Deliberation among Experts and Citizens. In Parkinson J and Mansbridge J (eds), Deliberative Systems: Deliberative Democracy at the Large Scale. Cambridge: Cambridge University Press, pp. 27-51.

Collins H and Evans R (2004) Rethinking Expertise. Chicago: University of Chicago Press.

Curtin D (2017) 'Accountable Independence' of the European Central Bank: Seeing the Logics of Transparency. European Law Journal 23(1-2), 28-44. https://doi.org/10.1111/eulj.12211.

Dawson M, Maricut-Akbik A and Bobić A (2019) Reconciling Independence and Accountability at the European Central Bank: The False Promise of Proceduralism. European Law Journal 25(1), 75-93. https://doi.org/10.1111/eulj.12305.

De Haan J and Eijffinger SCW (2000) The Democratic Accountability of the European Central Bank: A Comment on Two Fairy-Tales. Journal of Common Market Studies 38(3), 393-407. https://oi.org/10. 1111/1468-5965.00227.

della Porta D (2020) A Europe of Struggles: Blockupy as a Political Moment. European Journal of Cultural and Political Sociology 7(3), 378-404. https://doi.org/10.1080/23254823.2020.1779599.

Di Fabio U (2014) Karslruhe Makes a Referral. German Law Journal 15(2), 107-110. https://doi.org/10. 1017/S2071832200002868. 
Dietsch P (2019) Independent Agencies, Distribution, and Legitimacy: The Case of Central Banks. American Political Science Review, published early online, December. https://doi.org/10.1017/ S0003055419000790.

Dietsch P, Claveau F and Clément F (2018) Do Central Banks Serve the People? Cambridge: Polity.

Dyson K and Featherstone K (1999) The Road to Maastricht: Negotiating Economic and Monetary Union. Oxford: Oxford University Press.

Ebrahim A and Weisband E (eds) (2007) Global Accountabilities. Cambridge: Cambridge University Press.

Eijffinger SC, Mahieu RJ and Raes L (2018) Inferring Hawks and Doves from Voting Records. European Journal of Political Economy 51(C), 107-120. https:/doi.org/10.1016/j.ejpoleco.2017.03.004.

Elliott KJ (2020) Democracy's Pin Factory: Issue Specialization, the Division of Cognitive Labor, and Epistemic Performance. American Journal of Political Science 64(2), 385-397. https:/doi.org/10.1111/ ajps.12486.

European Central Bank (2019) Media: Executive Board - Communications Guidelines; ECB Forum on Central Banking. www.ecb.europa.eu/press/html/index.en.html.

European Parliament (2014) ECB's Replies to the Questionnaire of the European Parliament Supporting the Own Initiative Report Evaluating the Structure, the Role and Operations of the 'Troika' (Commission, ECB and the IMF) Actions in Euro Area Programme Countries. Brussels: European Parliament.

Fishkin JS (2018) Democracy When the People are Thinking: Revitalizing our Politics Through Public Deliberation. New York: Oxford University Press.

Fontan C (2018) Frankfurt's Double Standard: The Politics of the European Central Bank During the Eurozone Crisis. Cambridge Review of International Affairs 31(2), 162-182. https://doi.org/10.1111/j. 1468-5965.2012.02275.x.

Fontan C, Carré E and L'Oeillet G (2018) Theoretical Perspectives on the New Era of Central Banking. French Politics 16(4), 453-470. https://doi.org/10.1057/s41253-018-0067-8.

Gardt M, Bitterlich MT and Glöckler G (2019) Beyond Expert Circles: Measuring Central Banks' Engagement with the Wider Public. Paper presented at EUSA International Biennial Conference, 9-11 May, Denver, Colorado.

Grant RW and Keohane RO (2005) Accountability and Abuses of Power in World Politics. American Political Science Review 99(1), 29-43. https://doi.org/10.1017/S0003055405051476.

Grimm D (2020) A Long Time Coming. German Law Journal 21(5), 944-949. https://doi.org/10.1017/glj. 2020.55.

Haas PM (1992) Introduction: Epistemic Communities and International Policy Coordination. International Organization 46(1), 1-35. https://doi.org/10.1017/S0020818300001442.

Heldt EC (2018) Lost in Internal Evaluation: Accountability and Insulation at the World Bank. Contemporary Politics 24(5), 568-587. https://doi.org/10.1080/13569775.2018.1455491.

Heldt EC and Müller T (2020) The (Self)-Empowerment of the European Central Bank During the Sovereign Euro Crisis. Journal of European Integration. Published early online, February. https://doi. org/10.1080/07036337.2020.1729145.

Holst C and Molander A (2017) Public Deliberation and the Fact of Expertise: Making Experts Accountable. Social Epistemology 31(3), 235-250. https://doi.org/10.1080/02691728.2017.1317865.

Hood C (2010) Accountability and Transparency: Siamese Twins, Matching Parts, Awkward Couple? West European Politics 33(5), 989-1009. https://doi.org/10.1080/01402382.2010.486122.

Howarth D and Loedel P (2005) The European Central Bank: The New Leviathan. Basingstoke: Palgrave Macmillan.

Issing $\mathbf{O}$ (1999) The Eurosystem: Transparent and Accountable or Willem in Euroland. Journal of Common Market Studies 37(3), 503-519. https://doi.org/10.1111/1468-5965.00175.

Jabko N (2009) Transparency and Accountability. In Dyson K and Marcussen M (eds), Central Banks in the Age of the Euro. Oxford: Oxford University Press, pp. 391-406.

Janis IL (1972) Victims of Groupthink: A Psychological Study of Foreign-Policy Decisions and Fiascos. Boston: Houghton-Mifflin.

Jones E and Matthijs M (2019) Beyond Central Bank Independence: Rethinking Technocratic Legitimacy in Monetary Affairs. Journal of Democracy 30(2), 127-141. https://doi.org/10.1353/jod.2019.0030.

Keohane R, Lane $\mathbf{M}$ and Oppenheimer M (2014) The Ethics of Scientific Communication Under Certainty. Politics Philosophy \& Economics 13(4), 343-368. https://doi.org/10.1177/1470594X14538570. 
Koop C and Hanretty C (2018) Political Independence, Accountability, and the Quality of Regulatory Decision-Making. Comparative Political Studies 51(1), 38-75. https://doi.org/10.1177/0010414017695329.

Mansbridge J et al. (2012) A Systemic Approach to Deliberative Democracy. In Parkinson J and Mansbridge J (eds), Deliberative Systems. Deliberative Democracy at the Large Scale. Cambridge: Cambridge University Press, pp. 1-26.

Marcussen M (2009) Scientization of Central Banking: The Politics of A-Politicization. In Dyson K and Marcussen M (eds), Central Banks in the Age of the Euro. Oxford: Oxford University Press, pp. 373-390.

McNamara KR (2012) The ECB is Hampered by a Lack of Democratic Legitimacy, Despite Being Responsible for Policies Hugely Consequential for the Lives of European Citizens. London School of Economics and Political Science blog. http://bit.ly/MB2DAg.

Millgram E (2015) The Great Endarkenment: Philosophy for an Age of Hyperspecialization. New York: Oxford University Press.

Mudge D and Vauchez A (2016) Fielding Supranationalism: The European Central Bank as a Field Effect. Sociological Review Monograph 64(2), 146-169. https://doi.org/10.1002/2059-7932.12006.

O’Neill O (2014) Trust, Trustworthiness, and Accountability. In Morris N and Vines D (eds), Capital Failure: Rebuilding Trust in Financial Services. Oxford: Oxford University Press, pp. 172-191.

Pasquale F (2010) Beyond Innovation and Competition: The Need for Qualified Transparency in Internet Intermediaries. Northwestern University Law Review 104(1), 105-174.

Petersen N (2014) Karslruhe Not only Barks, but Finally Bites: Some Remarks on the OMT Decision of the German Constitutional Court. German Law Journal 15(2), 321-327. https://doi.org/10.1017/ S2071832200002960.

Riles A (2018) Financial Citizenship: Experts, Publics, and the Politics of Central Banking. Ithaca: Cornell University Press.

Schmidt V (2013) Democracy and Legitimacy in the European Union Revisited: Input, Output, and 'Throughput'. Political Studies 61(1), 2-22. https://doi.org/10.1111/j.1467-9248.2012.00962.x.

Scholte JA (2011) Building Global Democracy? Civil Society and Accountable Global Governance. Cambridge: Cambridge University Press.

Schrefler L (2010) The Usage of Scientific Knowledge by Independent Regulatory Agencies. Governance: An International Journal of Policy, Administration, and Institutions 23(2), 309-330. https://doi.org/10. 1111/j.1468-0491.2010.01481.x.

Schulz DF (2017) Too Little, Too Late? How Central Bankers' Beliefs Influence What They Do. Florence: European University Institute.

Steffek J (2018) The Limits of Proceduralism: Critical Remarks on the Rise of 'Throughput Legitimacy'. Public Administration 97(4), 784-796. https://doi.org/10.1111/padm.12565.

Tallberg J, Sommerer T, Squatrito T and Jönsson C (2013) The Opening Up of International Organizations: Transnational Access in Global Governance. Cambridge: Cambridge University Press.

Van Rompuy H (2012) Towards a Genuine Economic and Monetary Union. Report, 26 June. Brussels: European Council - The President. EUCO 120/12. http://bit.ly/2F3ubk5.

van't Klooster J (2018) Democracy and the European Central Bank's Emergency Power. Midwest Studies in Philosophy 42(1), 270-293. https://doi.org/10.1111/misp.12094.

van't Klooster J (2019) A Parliament for the Eurozone. In Twelve Stars: Philosophers Chart a Course for Europe. Gütersloh: Verlag Bertelsmann Stiftung, p. 84.

Weigner L (2020) Lagarde stellt flexiblere Handhabe des Inflationsziels in Aussicht. FinanzBusiness.de, 30 September. https://finanzbusiness.de/nachrichten/regulierung/article12452298.ece?utm_campaign=unicredit \&utm_source=corp_feed\&utm_medium=rss.

Cite this article: Heldt EC, Herzog L (2022). The Limits of Transparency: Expert Knowledge and Meaningful Accountability in Central Banking. Government and Opposition: An International Journal of Comparative Politics 57, 217-232. https://doi.org/10.1017/gov.2020.36 